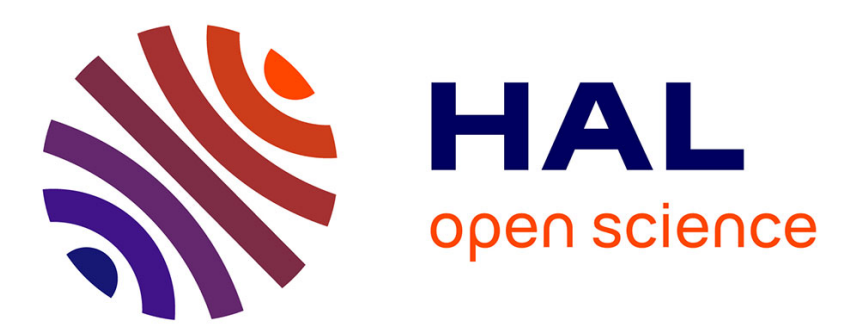

\title{
Evidence for an androgen binding protein in the testis of a teleost fish (Salmo gairdneri): a potential marker of sertoli cell function
}

Jean-Luc Foucher, Florence Le Gac

\section{- To cite this version:}

Jean-Luc Foucher, Florence Le Gac. Evidence for an androgen binding protein in the testis of a teleost fish (Salmo gairdneri): a potential marker of sertoli cell function. Journal of Steroid Biochemistry, 1989, 32 (4), pp.545-552. 10.1016/0022-4731(89)90388-9 . hal-02728270

\section{HAL Id: hal-02728270 \\ https: / hal.inrae.fr/hal-02728270}

Submitted on 2 Jun 2020

HAL is a multi-disciplinary open access archive for the deposit and dissemination of scientific research documents, whether they are published or not. The documents may come from teaching and research institutions in France or abroad, or from public or private research centers.
L'archive ouverte pluridisciplinaire HAL, est destinée au dépôt et à la diffusion de documents scientifiques de niveau recherche, publiés ou non, émanant des établissements d'enseignement et de recherche français ou étrangers, des laboratoires publics ou privés. 


\title{
EVIDENCE FOR AN ANDROGEN BINDING PROTEIN IN THE TESTIS OF A TELEOST FISH (SALMO GAIRDNERI R.): A POTENTIAL MARKER OF SERTOLI CELL FUNCTION
}

\author{
Jean-LuC Foucher* and Florence Le GaC \\ Laboratoire de Physiologie des Poissons, Institut National de la Recherche Agronomique, Campus de \\ Beaulieu, 35042 Rennes Cédex, France
}

(Received 17 February 1988; received for publication 27 October 1988)

\begin{abstract}
Summary-A factor binding tritiated testosterone was detected using "steady-state" polyacrylamide-gel electrophoresis, in rainbow trout genital tract. It migrated with a $R_{\mathrm{f}}$ identical to that of rat $\mathrm{ABP}$. This binding was thermolabile, and was competitively inhibited by unlabelled testosterone. The steroid binding protein was found in cytosols from trout testes which had been previously perfused to avoid blood contamination, trout seminal plasma and in testicular explants incubation media. Using a quantitative assay and a Scatchard analysis, $25-50$ pmol binding sites per gram gonad were found in testis cytosol. Binding affinity constant for testosterone in the various samples was close to $4 \times 10^{8} \mathrm{M}^{-1}$. The dissociation of steroid-protein complex was rapid $\left(t_{1 / 2} \approx 1.5 \mathrm{~min}\right)$. Hormonal specificity was studied by the competition of ${ }^{3} \mathrm{H}-\mathrm{T}$ binding with several concentrations of unlabelled competitors and the following order for affinities was obtained:

dihydrotestosterone $\approx$ androstenedione $>$ testosterone $>$ oestradiol $>17 \alpha, 20 \beta$ DHP

$>11 \mathrm{KT}>$ cyproterone acetate $>$ cortisol.

High testicular cytosol and seminal plasma concentrations and apparent in vitro production indicate that the testis may synthesize an ABP-like protein in the trout. Such a factor would provide a unique marker of Sertoli cell activity and regulation in various physiological or experimental situations.
\end{abstract}

\section{INTRODUCTION}

Although steroidogenic potential has been associated with Sertoli cells in teleost fish [1-3], neither 11 ketotestosterone (11KT) nor $17 \alpha$-hydroxy, $20 \beta$ dihydroprogesterone $(17 \alpha, 20 \beta$ DHP) have been detected in trout Sertoli cell primary culture [4]. In fact, most studies on fish Sertoli cells have been concerned with their morphology $[5,6]$. However, their close anatomical relationship with germ cells and their involvement in the blood-testis barrier [7,8] suggest a role in the regulation of spermatogenesis.

Numerous in vivo and in vitro studies have shown the major action of maturational gonadotropin $(\mathrm{GtH})$ on steroidogenesis, and of $\mathrm{GtH}$ and androgens on gametogenesis in male fish $[9,10]$. However, a direct action of hormones on the intralobular com-

*Address for correspondence: Laboratoire de Physiologie des Poissons, INRA, Campus de Beaulieu, 35042 Rennes Cédex, France.

Abbreviations: dihydrotestosterone: $17 \beta$-hydroxy- $5 \alpha-$ androstan-3-one; testosterone (T): 17 $\beta$-hydroxy-4androsten-3-one; androstenedione: 4-androstene-3, 17-dione; 11 ketotestosterone (1IKT): $17 \beta$-hydroxy-4androsten-3,11-dione; oestradiol (E2): 1,3,5(10)-oestratriene-3,17 $\beta$-diol; progesterone: 4-pregnene-3,20-dione; $17 \alpha$ hydroxy $20 \beta$ dihydroprogesterone $(17 \alpha, 20 \beta$ DHP): $17 \alpha, 20 \beta$-dihydroxy-4-pregnene-3-one; cortisol: $11 \beta, 17$, 21-trihydroxy-4-pregnene-3,20-dione; cyproterone acetate: $17 \alpha$-hydroxy-1,2 $\alpha$-methylene-6-chloro-4,6-pregna diene-3,20-dione. partment and in particular on Sertoli cells has yet to be demonstrated. This is essentially due to the lack of a simple assay of the activity of these cells.

In several mammalian species, the action of androgens on the genital tract is believed to be modulated by an androgen binding protein (ABP) specifically produced in the testis by the Sertoli cells. ABP is present in the seminal plasma of several mammals [11] and its secretion is regulated by FSH and testosterone [12-14]. A steroid binding protein (SBP) is also found in the blood of numerous vertebrates, including salmonids [15-17].

The aim of the present study was to investigate steroid binding in the trout testis and seminal plasma, in search of an ABP-like component. Such a protein would eventually provide a very useful tool to study Sertoli cell function and regulation in fish.

This work has been partially presented at the "First International Symposium on Binding Proteins: Steroid Hormones" [18] and in the "Third International Symposium on Reproductive Physiology of Fish" [19].

\section{EXPERIMENTAL}

\section{Animals}

Two or three year old male rainbow trout were obtained from a fish farm and kept in the laboratory in a recirculating water system at $12^{\circ} \mathrm{C}$. 


\section{Chemicals}

$\left[1,2,6,7 \cdot{ }^{3} \mathrm{H}\right]$ testosterone $(90 \mathrm{Ci} / \mathrm{mM})$ was obtained from Amersham. Unlabelled steroids were purchased from Steraloids (U.S.A.).

\section{Testis cytosol preparation}

Freshly collected testes were perfused with heparinised saline, to eliminate blood contamination. The tissues were minced and homogenized in $4 \mathrm{vols}$ buffer $\mathrm{A}$ (Tris $\mathrm{HCl} 10 \mathrm{mM}$, EDTA $1.5 \mathrm{mM}$, monothioglycerol $12 \mathrm{mM}, 10 \%$ vol. glycerol; $\mathrm{pH} 7.8$ ), with a tissue homogenizer (Polytron PC U2 KinematicaSwitzerland), in the presence of $1 \mathrm{mM}$ phenylmethylsulfonyl fluoride (PMSF). Homogenates were centrifuged at $2000 \mathrm{~g}(15 \mathrm{~min})$ and $105,000 \mathrm{~g}(60 \mathrm{~min})$ successively. Pellets were discarded. The resulting supernatants (cytosols) were kept at $-30^{\circ} \mathrm{C}$ until used.

\section{Incubation of testicular explants}

Testis blood vessels were perfused with $10 \mathrm{ml}$ incubation medium (in $m M: \mathrm{NaCl} 133 ; \mathrm{KCl} \mathrm{3.1;}$ $\mathrm{MgSO}_{4} 0.3 ; \mathrm{MgCl}_{2} 1.0 ; \mathrm{CaCl}_{2}$ 3.4; glucose 5.5; Hepes $\mathrm{NaOH} 40-[20])$ and the tissue minced in $8 \mathrm{~mm}^{3}$ blocs. These explants were washed 3 times in a large volume of culture medium, then incubated for $24 \mathrm{~h}$ at $12^{\circ} \mathrm{C}$ in plastic culture dishes $(6$ wells; NUNC, Denmark).

In each well, 15-20 explants were added to $3 \mathrm{ml}$ of incubation medium buffered with Hepes $40 \mathrm{mM}$ (pH 7.8) and complemented with amino acids and vitamins (Basal medium (Eagle) solutions-GIBCO). At the end of the experiment, tissues and media were separated by centrifugation and kept separately at $-30^{\circ} \mathrm{C}$. Tissues were subsequently processed as described for testis cytosol preparation.

When indicated, pituitary extracts were added to the media at the beginning of the experiment. Pituitaries were homogenized with a teflon-glass Potter homogenizer, in Tris- $\mathrm{HCl} 50 \mathrm{mM}$ buffer (pH 7.8), containing $0.5 \mathrm{M} \mathrm{NaCl}, 0.2 \mathrm{mM}$ dithiothreitol, $1 \mathrm{mM}$ $\mathrm{CaCl}_{2}, 1 \mathrm{mM} \mathrm{MgCl}$ and $1 \mathrm{mM} \mathrm{MnCl}$; with addition of $1 \mathrm{mM}$ paraaminobenzamidine and $1 \mathrm{mM}$ PMSF. The supernatant of a $1 \mathrm{~h}, 1800 \mathrm{~g}$ centrifugation, kept at $-70^{\circ} \mathrm{C}$ was used as crude pituitary extract.

Steady state polyacrylamide gel electrophoresis (SS-PAGE)

SS-PAGE was performed as previously described by Ritzen[21], Samples were preincubated with $4 \mathrm{nM}$ $\left[{ }^{3} \mathrm{H}\right]$ testosterone $\left({ }^{3} \mathrm{H}-\mathrm{T}\right)$. At the end of the electrophoretic migration in $6.5 \%$ acrylamide, $0.5 \%$ bis acrylamide gels containing $2 \mathrm{nM}^{3} \mathrm{H}-\mathrm{T}$, the cylindrical geis were cut into $2 \mathrm{~mm}$ slices and the radioactivity of each slice counted.

Assay of steroid binding protein using DEAE bio gel [22]

Aliquots $(100 \mu 1)$ of samples were incubated for $45 \mathrm{~min}$ in glass tubes coated with silicone, with $300 \mu \mathrm{l}$ buffer $A$ and $150 \mu l$ of washed DEAE bio gel diluted $1: 2$ in buffer $A$. After centrifugation $(1000 \mathrm{~g}, 5 \mathrm{~min})$, the supernatant was discarded and ${ }^{3} \mathrm{H}-\mathrm{T}$ was added to DEAE-protein complex; (total vol.: $300 \mu \mathrm{I}$ ). In a second series of tubes, ${ }^{3} \mathrm{H}-\mathrm{T}$ was added together with a 300 -fold excess of unlabelled testosterone to determine non specific binding (NSB). Incubations were stopped after $2 \mathrm{~h}$ and DEAE-binding proteinstestosterone complexes collected on Whatman GFA filters (set on a Millipore 12 places filtering manifold) and separated from free ${ }^{3} \mathrm{H}-\mathrm{T}$ by washing tubes and filters with $4 \times 3 \mathrm{ml}$ buffer $A$. Each tube was treated in less than $7 \mathrm{~s}$. Filters were dried then counted with $5 \mathrm{ml}$ of scintillation counting solution (OCS) in $6 \mathrm{ml}$ counting vials in a Packard TRI CARB 4000 series counter. Incubation times, volumes and washing conditions were optimised to suit our material. $\left[{ }^{3} \mathrm{H}\right]$ steroid binding to DEAE and filter disk (blank) was found to be less than $2 \%$ of total added counts. Error on specific binding (SB) determination due to changes of the blanc in the presence of unlabelled hormones was found to be negligible.

\section{RESULTS}

\section{SS-PAGE}

Polyacrylamide gel electrophoresis at equilibrium, in the presence of ${ }^{3} \mathrm{H}$-T revealed a saturable testosterone binding site in trout testis cytosol (Fig. 1a). In a $6.5 \%$ acrylamide gel, this binding factor had a mobility relative to bromophenol blue $\left(R_{\mathrm{f}}\right)$ of 0.44 . Conditioned media of testis explants, trout seminal plasma and blood plasma all contained a testosterone binding factor migrating with a similar $\boldsymbol{R}_{\mathrm{f}}(\mathbf{0 . 4 3 -}$ 0.45 -Fig. I; b-d). Under similar conditions, ABP from an adult male rat epididymis cytosol presented an identical $R_{f}$ (data not shown).

\section{Thermolability}

Testosterone specific binding activity was measured in cytosol samples maintained for $30 \mathrm{~min}$ at different temperatures. Specific binding was reduced by $40 \%$ at $30^{\circ} \mathrm{C}, 75 \%$ at $50^{\circ} \mathrm{C}$ and $100 \%$ at $60^{\circ} \mathrm{C}$ compared with sample preincubated $30 \mathrm{~min}$ at $4^{\circ} \mathrm{C}$.

\section{Association and dissociation}

Specific binding was measured after different times of incubation of DEAE-protein complex (see experimental) with $4 \mathrm{nM}{ }^{3} \mathrm{H}-\mathrm{T}$. At $4^{\circ} \mathrm{C}$, association was very rapid and reached a maximum level after $2 \mathrm{~h}$ of incubation (Fig. 2). For the dissociation study, a set of aliquots of testis cytosol was equilibrated with $4 \mathrm{nM}{ }^{3} \mathrm{H}$-T. Unlabelled testosterone $(3000 \mathrm{nM})$ was then added to the incubates and specific binding measured after different periods of time (Fig. 3). Dissociation occurred extremely rapidly and the half-time of dissociation of the complex $\left(t_{1 / 2}\right)$ was 1-2 min. Study of binding kinetics allowed us to determine the constants of rate of association $\left(k_{1}=1.06 \times 10^{8} \mathrm{M}^{-1} \mathrm{~min}^{-1}\right)$ and dissociation $\left(k_{2}=\right.$ 

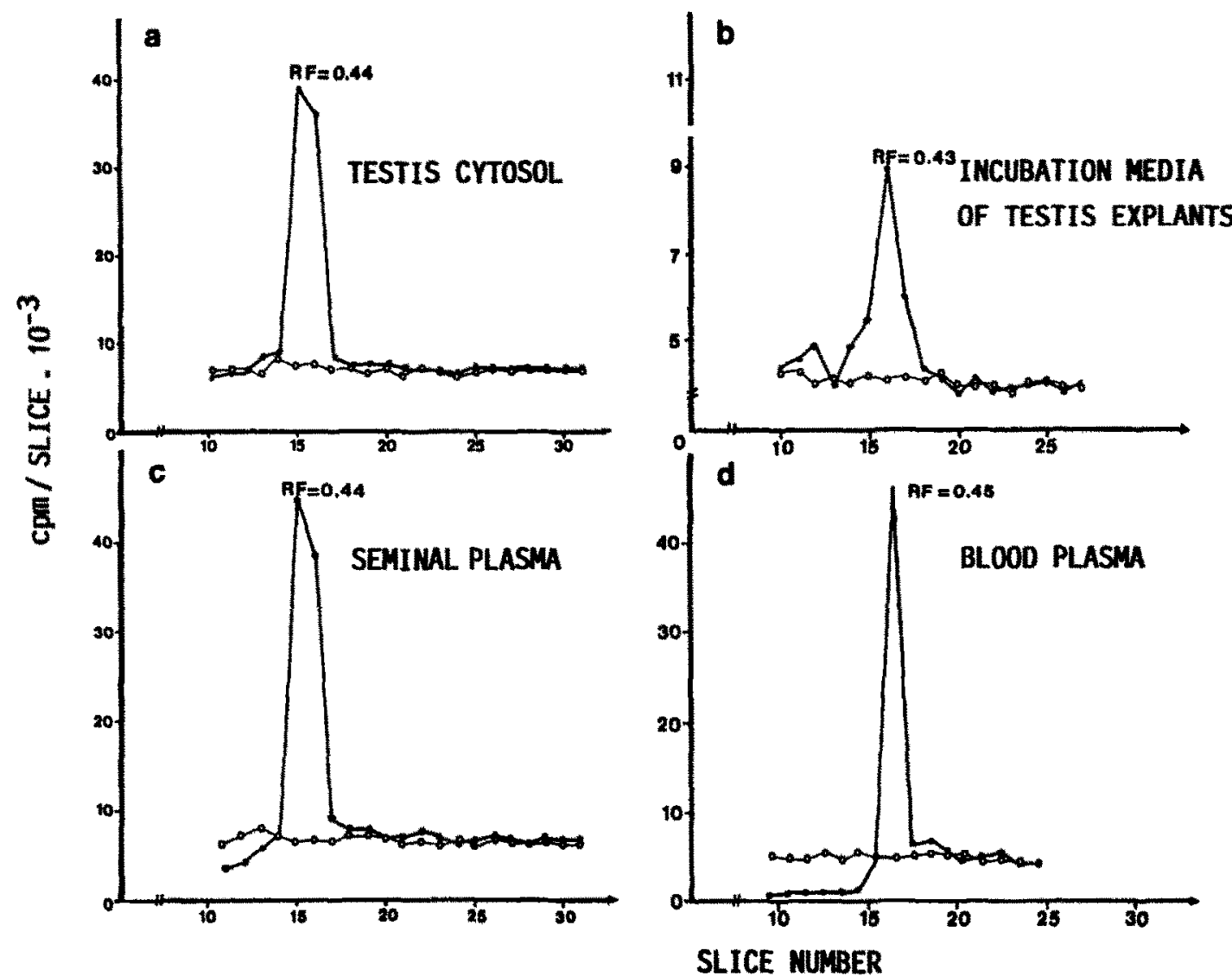

Fig. 1. Polyacrylamide gel electrophoresis of different samples in gels containing $2 \mathrm{nM}{ }^{3} \mathrm{H}-\mathrm{T}$, in the presence $(O)$ or not $(O)$ of excess unlabelled $\mathrm{T}(800 \mathrm{nM})$. After electrophoresis, the gels were sliced and radioactivity determined in each slice.

$\left.4.2 \times 10^{-1} \mathrm{~min}^{-1}\right)$. The association constant value calculated from initial rates of association and dissociation $\left(K_{s}=k_{1} / k_{2}\right)$ was found to be $2.5 \times 10^{8} \mathrm{M}^{-1}$. This value is in the same order of magnitude as the $K_{a}$ obtained from Scatchard analysis (see below).

The assay used in this study allows a very fast separation of bound and free hormone at the end of incubations $(7 \mathrm{~s})$, which prevents dissociation during this step. As a consequence, this method was preferred to the dextran coated charcoal assay (DCC: 15 min treatment with $0.1 \%$ charcoal $+0.01 \%$ dextran at $0^{\circ} \mathrm{C}+15 \mathrm{~min}$ centrifugation at $4000 \mathrm{~g}$ ) which was found to largely underestimate the number of specific binding sites present in trout testicular cytosols.

\section{Saturation analysis}

Aliquots of samples were incubated for $2 \mathrm{~h}$ with increasing concentrations of ${ }^{3} \mathrm{H}-\mathrm{T} \quad(0.5-16 \mathrm{nM})$. Plotting of ${ }^{3} \mathrm{H}-\mathrm{T}$ specific binding measured as a function of hormone concentration demonstrates the saturability of the binding sites (Fig. 4). Scatchard plot analysis of saturation experiments (Fig. 5) allowed determination of the number of binding sites and their affinity constants.

Such analysis was carried out in testis cytosols prepared at different stages of the reproductive cycle as well as in seminal plasma and blood plasma (Table 1). The concentration of binding sites decreased from 50 to 25 pmol per gram of gonad during the sexual cycle. However, the total amount of binding protein contained in a pair of testicles dramatically increased during the same period. Binding protein concentration varied in seminal plasma of different individuals $(30-100 \mathrm{pmol} / \mathrm{ml})$ and was always high in the male blood plasma (350$750 \mathrm{pmol} / \mathrm{ml})$. The affinity constant was always close to $4 \times 10^{8} \mathrm{M}^{-1}$.

\section{Steroid specificity}

Steroid hormone specificity of trout testis binding protein was determined by incubating aliquots of testis cytosol with $1 \mathrm{nM}$ of ${ }^{3} \mathrm{H}-\mathrm{T}$ in competition with increasing concentrations of differents unlabelled steroids (Fig. 6). For each concentration of competitor, specific binding of tritiated steroid was determined and expressed as percent of specific binding in the absence of competitor $\left(B / B_{0} \%\right)$. Inhibition curves were linearized (logit $B / B_{0}$ as a function of $\log$ of steroid concentration) to enable determination of the competitor concentration required to bring about $50 \%$ inhibition. The relative steroid affinities were determined as shown in Table 2. Affinity was higher for androgens than for other sex steroids, with the 


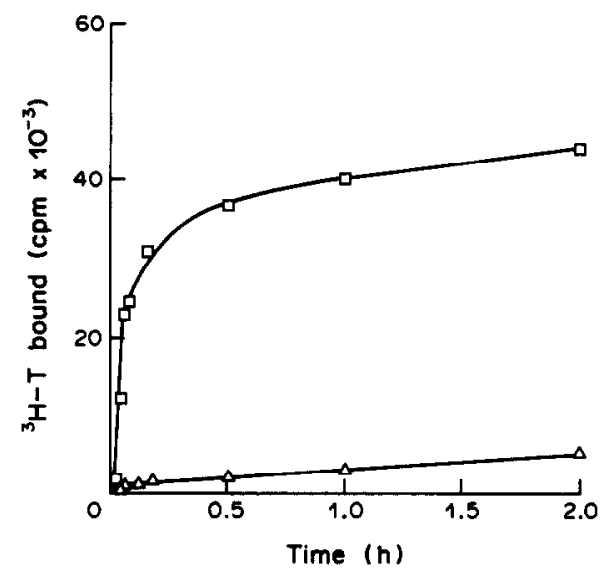

Fig. 2. One representative experiment showing kinetics of association of ${ }^{3} \mathrm{H}-\mathrm{T}$ to binding sites in a trout testis cytosol. Aliquots of testis cytosol were incubated with $4 \mathrm{nM}{ }^{3} \mathrm{H}-\mathrm{T}$ plus or minus a 300 -fold excess unlabelled $T$ for the times indicated. Binding was determined as described in methods. $\square$ : specific binding, $\Delta$ : non specific binding (each point is the mean of duplicate determinations).

exception of $11 \mathrm{KT}$. Corticosteroids and cyproterone acetate, an antiandrogen known to bind androgen receptors, were poor competitors.

\section{In vitro production of binding protein}

Testis explants were incubated as described above. Supernatants of incubation were collected and media renewed at different times during a $24 \mathrm{~h}$ period. Figure 7 gives cumulative amounts of binding protein measured in media ( $\mathrm{pmol} / \mathrm{g}$ explants) as a function of incubation time. Accumulation of binding activity in media was rapid during the first $6 \mathrm{~h}$ of incubation $(5.5 \mathrm{pmol} / \mathrm{h})$ but slower during the last $4 \mathrm{~h}$ $(1.1 \mathrm{pmol} / \mathrm{h})$.

In order to rule out the hypothesis of a simple release of binding protein by testis explants, amounts of binding activity were measured in tissues at the beginning of incubation as well as in media and

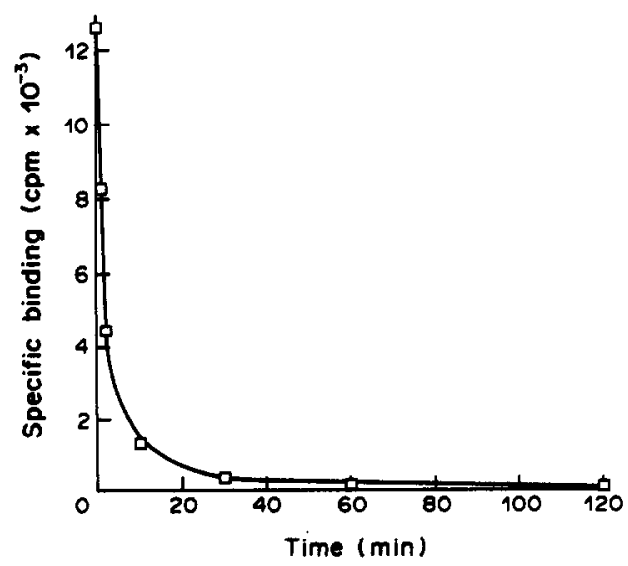

Fig. 3. Representative study of dissociation kinetics of ${ }^{3} \mathrm{H}-\mathrm{T}$ binding protein complex. Trout testis cytosol was incubated with $4 \mathrm{nM}{ }^{3} \mathrm{H}-\mathrm{T}$ to equilibrium. Specific binding was measured at different time after the addition of a large excess of unlabelled $\mathrm{T}\left(t_{1 / 2}=1\right.$ to $\left.2 \mathrm{~min}\right)$.

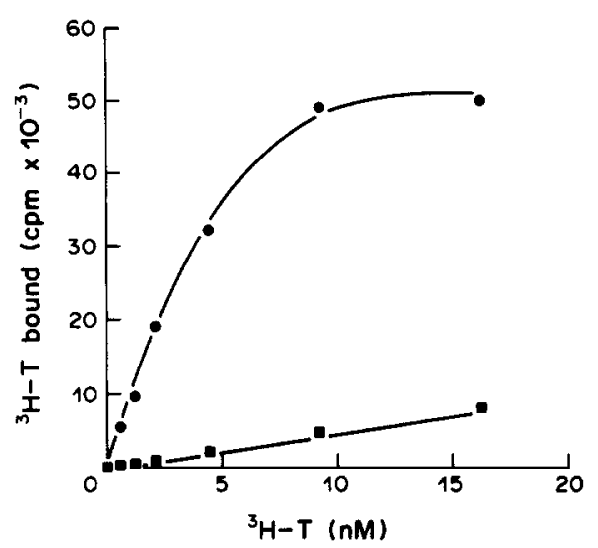

Fig. 4. Saturation analysis. Aliquots of cytosol from mature non spermiating testis were incubated with increasing amounts of ${ }^{3} \mathrm{H}$-T plus or minus a 300 -fold excess unlabelled T. Specific binding: 0 , non specific binding: 0 . Each value is the mean of duplicate determinations.

tissues at the end of two incubations periods: $0-1.5 \mathrm{~h}$ and $0-24 \mathrm{~h}$ (Fig. 8). In both cases, the total amount of binding protein (media + explants) measured at the end of incubation was significantly greater than that present initially in explants. Therefore, binding protein production seems to occur during incubations. Decrease in production between 1.5 and $24 \mathrm{~h}$ was found to result, at least in part, from a rapid degradation of binding activity in isolated testicular tissues tissues kept at $12^{\circ} \mathrm{C}$ (data not shown).

Hormonal influence on steroid binding protein production has been studied by addition of salmonid pituitary extracts (total or fractionated) and purified sGtH to the incubation media. Preliminary results, in pmol of binding protein accumulated in media after $24 \mathrm{~h}$ incubation (Fig. 9) do not show any significant effect of the various hypophysial preparations.

\section{DISCUSSION}

This study reveals the presence of a steroid binding activity in the trout genital tract. The binding component is thermolabile; it is saturable and presents

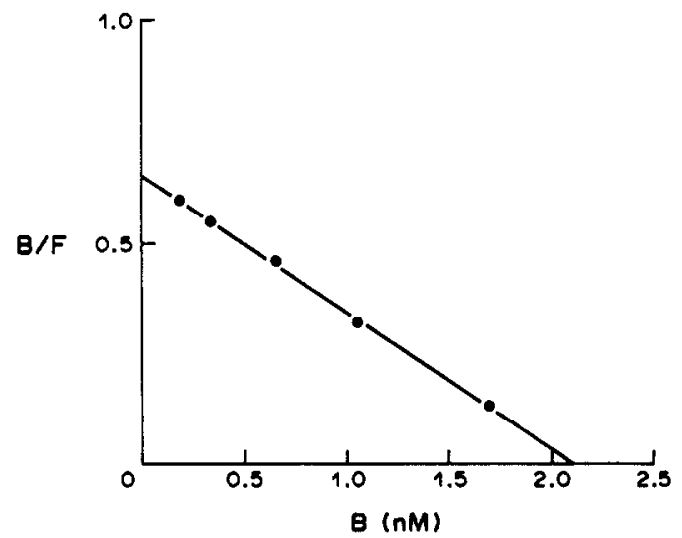

Fig. 5. Scatchard plot from saturation analysis shown in Fig. 4. $K_{a}=4 \times 10^{8} \mathrm{M}^{-1}$. 
Table 1. Testosterone binding in trout testis at different stages of gonadal development, in seminal plasma and in blood plasma

\begin{tabular}{|c|c|c|c|c|}
\hline \multirow{2}{*}{$\begin{array}{l}\text { Samples } \\
\text { Testicular cytosols }\end{array}$} & \multicolumn{3}{|c|}{ No. of binding sites } & \multirow{2}{*}{$\frac{\mathrm{Ka}\left(\mathrm{M}^{-1}\right)}{\mathrm{Mean} \pm \mathrm{SE}^{\mathrm{c}}}$} \\
\hline & $n$ & $\mathrm{pmol} / \mathrm{g}^{\mathrm{ac}}$ & $\mathrm{pmol} / 2 \mathrm{gon}^{\mathrm{bd}}$ & \\
\hline $\begin{array}{l}\text { - Beginning of Gametogenesis } \\
\text { - Prespermiation } \\
\text { - Spermiation } \\
\text { Testicular explants incubation media } \\
\text { - Beginning of Gametogenesis } \\
\text { - Prespermiation }\end{array}$ & $\begin{array}{l}3 \\
4 \\
4\end{array}$ & $\begin{array}{l}50 \pm 4 \\
22 \pm 2 \\
20 \pm 6 \\
53 \pm 2 \\
25 \pm 2\end{array}$ & $\begin{array}{c}15-50 \\
270-1500 \\
240-690 \\
\\
16-53 \\
275-1600\end{array}$ & $\begin{array}{c}4.1 \pm 0.3 \times 10^{8} \\
n=11 \\
4.2 \pm 0.4 \times 10^{8} \\
n=7\end{array}$ \\
\hline $\begin{array}{l}\text { Seminal plasma } \\
\text { Blood plasma }(\delta)\end{array}$ & & & & $\begin{array}{l}4.33 \times 10^{8} \\
3.8 \times 10^{8}\end{array}$ \\
\hline
\end{tabular}

high affinity for a limited number of steroids. These are characteristics of specific steroid binding proteins.

Specific binding does not seem to be due to a steroidogenic enzyme since in our incubation conditions we could not detect any metabolism of ${ }^{3} \mathrm{H}-\mathrm{T}$ (data not shown).

Several of the binding-protein features are similar to those of ABP secreted by Sertoli cells in mammals [12]. The trout factor migrates like rat ABP in PAGE; it presents higher affinity for androgens than for other sex-steroids and binds corticosteroids poorly; the protein-hormone complex dissociates very rapidly (1-2 min compared with a half time of dissociation of 5-12 $\mathrm{min}$ in mammals). The affinity for testosterone is comparable to that described for rat $\mathrm{ABP}\left(K_{a}=5.1 \times 10^{8} \mathrm{M}^{-1}\right)$, the number of binding sites varied from 25 to $50 \mathrm{pmol} / \mathrm{g}$ while it does not exceed $6 \mathrm{pmol} / \mathrm{g}$ testis in adult rat $[23,24]$. The presence of a high concentration of this bindingprotein in the trout genital tract made us carry on with our investigation of its nature and origin.

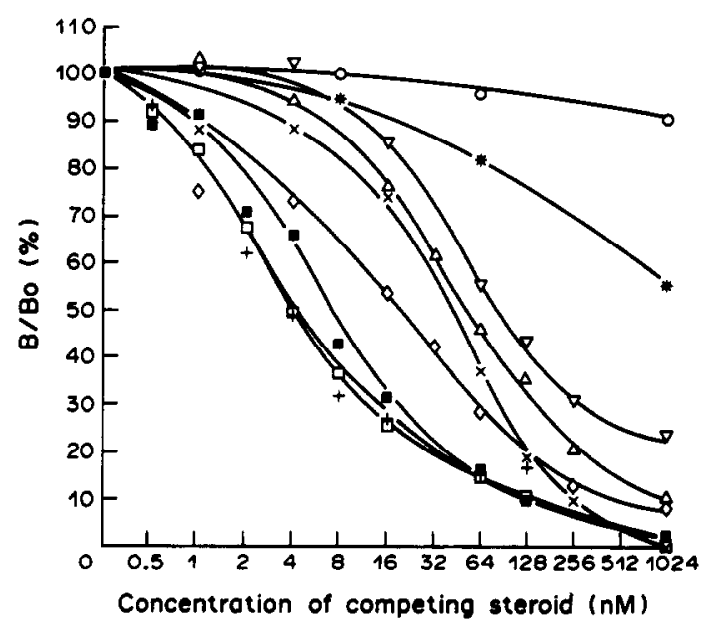

Fig. 6. Competition of various steroids with $1 \mathrm{nM}{ }^{3} \mathrm{H}-\mathrm{T}$ for binding sites in testis cytosol (diluted $1: 2$ ). Specific binding of ${ }^{3} \mathrm{H}-\mathrm{T}$ in absence of competitor is taken as $100 \%$. $\square$ : dihydrotestosterone, + : androstenedione, $\square$ : testosterone, $\diamond:$ oestradiol, $x$ : progesterone, $\triangle: 17 \alpha, 20 \beta-\mathrm{DHP}, \nabla$ : $11 \mathrm{KT}$, *: cyproterone acetate, $O$ : cortisol. Each point represent the mean of duplicate determinations.
The characteristics shown here are different from those usually described for androgen receptors: androgen receptors migrate more slowly in PAGE, usually show lower affinity for oestrogens and progestagens, higher affinity for cyproterone acetate, and clearly demonstrate a much slower dissociation of the steroid-protein complex (half-time of dissociation: $40-70 \mathrm{~min}$ ). Furthermore, the trout testicular binding protein poorly precipitates in $30 \%$ saturated ammonium sulfate (data not shown), and has high capacity compared to what is generally found for intracellular receptors [23, 25-27].

ABP is very similar to the sex steroid bindingprotein (SBP) found in serum of many species. The presence of high concentrations of SBP in trout blood plasma [16] raised the question of testicular cytosol contamination with blood. However, (i) from our estimation based on blood content in fish tissues, contamination cannot account for more than $10-20 \%$ of the measured testicular binding sites, (ii) the gonad circulatory system was perfused with saline before cytosol preparation. These facts indicate that a simple blood contamination can be excluded. We cannot yet rule out a physiological uptake and accumulation of SBP in the testis tissue. However, in vitro production of the binding activity argues for testicular ABP synthesis.

Furthermore, trout seminal plasma contains large concentrations of this binding factor. Establishment of the "blood-testis barrier" (tight junctions between Sertoli cells and also between epithelial cells of

Table 2. Relative steroid affinities for protein binding in testicular cytosol

\begin{tabular}{lc}
\hline Competing steroids & Relative affinities \\
\hline Dihydrotestosterone & 160 \\
Androstenedione & 167 \\
Testosterone & 100 \\
Oestradiol & 030 \\
Progesterone & 015 \\
$17 \alpha, 20 \beta \cdot D H P$ & 011 \\
$11-$ Ketotestosterone & 008 \\
Cyproterone acetate & $<1$ \\
Cortisol & $<1$
\end{tabular}

The affinity indices reported were obtained as follows: concentration of homologous unlabelled steroid necessary to displace $50 \%$ of ${ }^{3} \mathrm{H}$-T divided by the concentration of the competitor necessary to obtain the same effect and multiplied by 100 . 


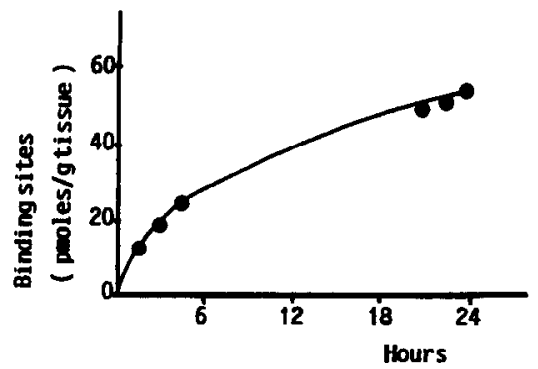

Fig. 7. Representative study of appearance of testosterone binding protein in testicular explant incubation media. At each point shown, the medium was removed for ABP assay and fresh medium was added. The graph is cumulative from the initial time of incubation.

the efferent ductules) occurs in teleosts before the beginning of sperm production $[7,8,28]$. In theory, this barrier does not allow diffusion of blood plasma proteins into the intralobular fluid. In that case high concentrations of binding activity in seminal plasma suggest a lobular origin of the binding protein.

The exact origin of the binding protein will only be clarified by using isolated testicular cells in culture. Such in vitro experimental work is now in progress in our laboratory.

There is evidence that androgens are involved in male fish gametogenesis, although it is not known at which particular step of this process. Testosterone and its derivatives administered after hypophysectomy are able to maintain or restore spermatogenesis in several fish species. In some cyclic fish, $11 \mathrm{KT}$ would be involved in the last stages of spermiogenesis and/or in the induction of spermiation, while $17 \alpha, 20 \beta$-DHP could regulate milt production during spawning [10].

Interaction of various steroids with $\mathrm{ABP}$ would depend on their respective affinity for the bindingprotein and also on their relative concentrations. Two important sex steroids in rainbow trout, $11 \mathrm{KT}$ and $17 \alpha, 20 \beta$-DHP are poor competitors of ${ }^{3} \mathrm{H}-\mathrm{T}$ binding. However, we have information suggesting that several steroids concentrations are 5-10 fold lower in seminal plasma than in blood plasma (Le Gac, unpublished data). We calculated that $100 \mathrm{nM}$ of binding-protein in seminal plasma $(100 \mathrm{pmol} / \mathrm{ml})$ could bind $80-99 \%$ of T, $60-70 \%$ of $17 \alpha, 20 \beta-\mathrm{DHP}$ and less than $55 \%$ of $11 \mathrm{KT}$. These figures suggest that the functional role of the binding protein might not concern exclusively the androgens with high affinity for the binding sites.

However, further discussion on the physiological significance of the relative affinities found in this study would necessitate more information on all the steroids present in seminal plasma (or various gonadal compartments) and susceptible to bind ABP. Furthermore, we cannot exclude that $11 \mathrm{KT}$ and/or $17 \alpha, 20 \beta$-DHP also bind to a high affinity site, different from the testosterone binding site described here and located either on the same protein or on another molecule.
Although the exact role of ABP remains to be established, in mammals it has been hypothesized that it concentrates androgens in the reproductive tract. However, steroid binding protein could act as a steroid buffer, reducing and stabilizing free steroid concentrations $[12,29]$. It is also possible that this extracellular factor facilitates the action of certain steroids on their target cells, functioning as a transmembrane carrier, as has been suggested for testosterone action on the caput epididymis of the rat [30]. In trout seminiferous lobules the germ cells are organized in cysts and are surrounded by Sertoli cells. In a cyst, spermatogenesis is synchronous. An ABP-like molecule might interfere with steroid concentrations in different spermatogenic cysts, as well as in intralobular or efferent duct fluids, and therefore might contribute to the steroidal regulation of gametogenesis.

ABP is specifically secreted by the Sertoli cells in the mammalian gonad. If a similar origin was demonstrated in fish, its measurement in trout testis would provide us with the first marker for studying Sertoli cell activity and regulation in teleosts. In this study, total testicular ABP-like content increased markedly during gonadal development. It is difficult to tell if this is linked to testicular cell multiplication during gonad maturation [4] or to a cyclic regulation of ABP-like production (or specific uptake) by a fixed number of cells. Preliminary experiments did not demonstrate an effect of crude pituitary extracts or purified maturational GtH on in vitro ABP-like production. However, the experimental conditions (i.e. age of animals, stage of gametogenesis, nonhypophysectomized animals) may have been inadequate for demonstrating an effect of the hormonal preparations.

Until now, fish testicular function was believed to be under the control of a unique gonadotropic hor-

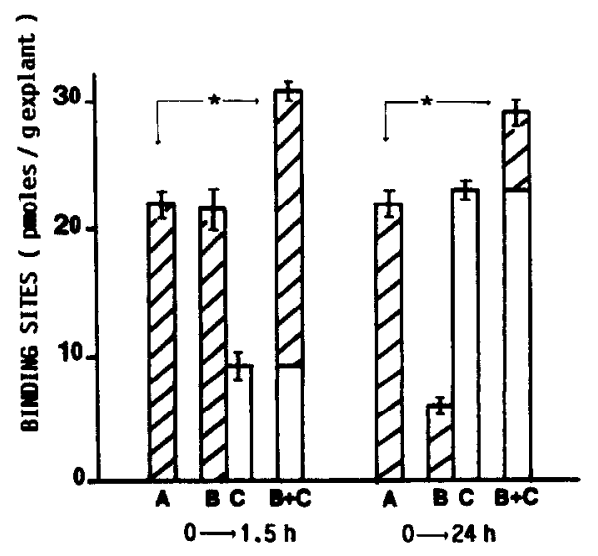

Fig. 8. In vitro production of testosterone binding protein. Amount of binding sites in: A: cytosols of non incubated testicular explants. B: cytosols of incubated explants. C: incubation media. B + C: explants + media after 2 incubation periods. Explants were prepared from a mature non spermiating testis. Identical results were found for other stages. $\left(^{*}\right)$ : Significant difference $(P<0.05$ for Students $t$-test). 


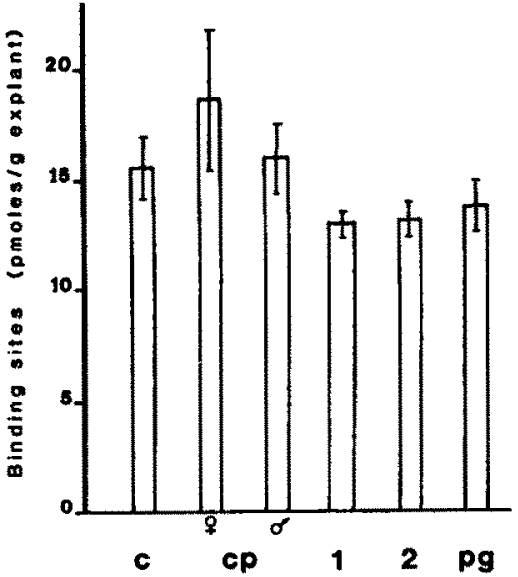

Fig. 9. Effect of various pituitary extract on in vitro production of steroid binding protein by testis tissue; explants were preincubated for $1.5 \mathrm{~h}$ and the media renewed before a $24 \mathrm{~h}$ incubation in the absence (c: control) or in presence of: (cp): crude pituitary extract from male or female origin; (1): fraction of a male pituitary extract not retained on Concanavalin A; (2): fraction retained on Concanavalin A; (pg) purified salmon maturational gonadotropin.

mone. Recently, Kawauchi and collaborators[31] claimed to have isolated a second gonadotropin, physicochemically different from the maturational GtH previously purified. However, no distinctive biological activity has been demonstrated for this new hormone and it would be of interest to investigate its effect on trout testicular content and/or production of steroid binding protein.

Acknowledgements-We thank Dr B. Jégou for giving us judicious advice and for critical reading of the manuscript, Dr A. Fostier for helpful discussions and collaborations and Dr B. Breton for the gift of Salmon GtH.

\section{REFERENCES}

1. Wiebe J. P.: Steroid dehydrogenases and steroids in gonads of the sea perch Cymatogaster aggregata Gibbons. Gen. Comp. Endocr. 12 (1969) 256-266.

2. Bara G.: Histochemical demonstration of $3 \beta-, 3 \alpha, 11 \beta$, and $17 \beta$-hydroxysteroid dehydrogenases in the testis of Fundulus heterocitus. Gen. Comp. Endocr. 13 (1969) $189-200$.

3. Van Den Hurk R., Vermeij J. A. J., Stegenga J., Peute J. and Van Oordt P. G. W.: Cyclic changes in the testis and vas deferens of the rainbow trout (Salmo gairdneri) with special reference to sites of steroidogenesis. Ann. Biol. Anim. Biochem. Biophys. 18 (1978) 899-904.

4. Loir M.: Trout Sertoli and Leydig cells: isolation, separation and culture. Gamete Res. 20 (1988) 437-458.

5. Billard R., Jalabert B. and Breton B.: Les cellules de Sertoli des poissons téléostéens. Ann. Biol. Anim. Biochem. Biophys. 12 (1972) 19-32.

6. Loir M.: Primary cultures of somatic testicular cells in the rainbow trout. In Les colloques de I'INRA. Bases fondamentales et appliquées en endocrinologie et génétique. Reproduction chez les poissons. In Press.

7. Abraham M., Rahamim E., Tibika H., Golenser E. and Kieselstein $M$.: The blood-testis barrier in Aphanius dispar (Teleostei). Cell Tissue Res. 211 (1980) 207-214.

8. Steyn G. J. and Van Huren J. H. J.: The role of the blood testis barrier in the chemical composition of the seminal plasma of the freshwater teleost Claria gariepinus. Comp. Biochem. Physiol. 3 (1986) 421-425.

9. Fostier A., Jalabert B., Billard R., Breton B. and Zohar Y.: The gonadal steroids. In Fish Physiology. (Edited by W. S. Hoar, D. J. Randall and E. M. Donaldson). Academic Press, New York, Vol IXA (1983) pp. 277-372.

10. Fostier A., Le Gac F. and Loir M.: Steroids in male reproduction. In Proceedings of the Third International Symposium on Reproductive Physiology of Fish (Edited by D. R. Idler, L. W. Crim and J. M. Walsh) (1988) p. 239.

11. Jégou B. and Le Gac-Jégou F:: Androgen-binding protein in the seminal plasma of some mammalian species. J. Endocr. 77 (1978) 267-268.

12. Tindall D. J. and Means A. R.: Properties and hormonal regulation of androgen binding proteins. In Advances in sex hormone research. (Edited by $\mathrm{J}$. A. Thomas and R. L. Singhal). Urban \& Schwartzenberg. Munich, Vol. 4 (1980) pp. 295-327.

13. Ritzen E. M., Hansson V. and French F. S.: Sertoli cell. In The testis. (Edited by H. Burger and D. de Kretzer) Raven Press, New York (1981) pp. 171-194.

14. Lobl T. J.: Androgen transport proteins: physical properties, hormonal regulation, and possible mechanism of TeBG and ABP action. Archs Androl. 7 (1981) 133-151.

15. Freeman H. C. and Idler D. R.: Binding affinities of blood proteins for sex hormones and corticosteroids in fish. Steroids 17 (1971) 233-250.

16. Fostier A. and Breton B.: Binding of steroids by plasma of a teleost: the rainbow trout, Salmo gairdneri. $J$. Steroid Biochem. 6 (1975) 345-351.

17. Pottinger T. G.: Seasonal variation in specific plasma- and target-tissue binding of androgens, relative to plasma steroid levels, in the brown trout, Salmo trutta L. Gen. Comp. Endocr. 70 (1988) 334-344.

18. Le Gac F., Foucher J. L., Fostier A. and Jégou B.: Androgen binding protein in the testis of a Teleost fish (Salmo gairdneri). In Proceedings of the first International Symposium on Binding Proteins: Steroid Hormones (Edited by M. G. Forest and M. Pugeat) Libbey/INSERM (1988) p. 646.

19. Le Gac F. and Foucher J. L.: Androgen binding protein in a teleost testis (Salmo gairdneri). In Proceedings of the third International Symposium on Reproductive Physiology of Fish. (Edited by D. R. Idler and J, M. Walsh) (1988) p. 261.

20. Jalabert B., Bry C, Szöllösi D. and Fostier A.: Etude comparé de l'action des hormones hypophysaires et stéroïdes sur la maturation in vitro des ovocytes de la truite et du carassin (Poisson téléostéen). Ann. Biol. Anim. Biochem. Biophys. 13 (1973) 50-73.

21. Ritzen E., French F. S., Weddington S. C., Nayfeh S. N. and Hansson V.: Steroid binding in polyacrylamide gels, quantitation at steady state conditions. I. Biol. Chem. 249 (1974) 6597-6604.

22. Johnson A. R., Holmes S. D., Lipshultz L. I. and Smith R. G.: Rapid method for quantitation of androgen binding protein in Sertoli cell cultures and its use for measurement of binding kinetics. J. Steroid Biochem. 22 (1985) 9-14.

23. Hansson V., Ritzen E. M., French F. S. and Nayfeh S. $\mathrm{N}$.: Androgen transport and receptor mechanisms in testis and epididimis. In Handbook of Physiology. (Edited by D. W. Hamilton and R. O. Greep). American Physiological Society, Washington. Sect. 7, Vol, 5 (1975) pp. 173-201.

24. Jégou B., Laws A. O. and de Kretser D. M.: The effect of cryptorchidism and subsequent orchidopexy on testicular function in adult rats. J. Reprod. Fert. 69 (1983) 137-145. 
25. Blondeau J. P., Corpéchot C., Le Goascogne C., Baulieu E. E. and Robel P.: Androgen receptors in the rat ventral prostate and their hormonal control. Vitam. Horm. 33 (1975) 319-344.

26. Hechter O., Mechaber D., Zwick A., Campfield L. A., Eychenne B., Baulieu E. E. and Robel P.: Optimal radioligand exchange conditions for measurement of occupied androgen receptor sites in rat ventral prostate. Archs Biochem. Biophys. 244 (983) 49-68.

27. Pottinger T. G.: Androgen binding in the skin of mature brown trout, Salmo trutta L. Gen. Comp. Endocr. 66 (1987) 224-232.

28. Bergman M., Schindelmeister J. and Greven $H$.: The blood-testis barrier in vertebrates having different testicular organization. Cell Tissue Res., 238 (1984) 145-150.
29. Bardin C. W., Musto N., Gunsalus G., Kotite N., Cheng S.-L., Larrea F. and Becker R.: Extracellular androgen binding proteins. Ann. Rev. Physiol. 43 (1981) 189-198.

30. Pelliniemi L. J., Dym M., Gunsalus G. L., Musto N. A., Bardin C. W. and Fawcett D. W.: Immunocytochemical localization of androgen-binding protein in the male rat reproductive tract. Endocrinology. 108 (1981) 925-931.

31. Kawauchi H., Suzuki K., Nagahama Y., Adachi S., Naito $N$. and Nakai $Y .:$ Occurrence of two distinct gonadotropins in chum salmon pituitary. In Pars Distalis of the Pituitary Gland-Structure, Function and Regulation. (Edited by F. Yoshimura and A. Gorbman). Elsevier, Amsterdam (1986) pp. 383-390. 